\title{
New Systems Thinking and Policy Means for Sustainable Energy Development
}

\author{
Niels I. Meyer ${ }^{1}$ \\ Technical University of Denmark, 2800 Lyngby, \\ Denmark
}

\section{Introduction}

Mitigation of the present global warming is a central challenge for a sustainable energy development. A major part of the global warming and the resulting climate change is due to combustion of fossil fuels with emission of $\mathrm{CO}_{2}$ as a dominating greenhouse gas (GHG).

The Intergovernmental Panel on Climate Change (IPCC) is analyzing the global climate changes and its findings have been published in a series of reports since 1991. Each report takes several years of preparation and the consequences of global warming have turned out to appear faster than foreseen in the latest report [IPCC 2007]. Several experts are estimating that irreversible "tipping points" are only few years ahead [Hansen et al. 2008, Kopp et al. 2009]. As a consequence they propose that the goal for the future $\mathrm{CO}_{2}$ concentration in the atmosphere should be as low as 350 ppm compared to the value in 2009 of about 387 ppm. A recent report from the National Research Council in the US has pointed out that the global warming will continue for several hundred years even if the GHG concentration is stabilized at the present level [National Research Council 2010].

So far, strategies for mitigation of global warming have mostly focused on technological solutions e.g. promotion of renewable energy sources (RES) on the supply side and energy efficiency on the demand side. Less attention has been given to potential contributions from changes in lifestyle and alternative economic, institutional and social systems.

Despite long and tedious preparations for COP15 in Copenhagen in December 2009, the final result [Copenhagen Accord 2009] lacked concrete commitments for reduction of GHGs after 2012 when the Kyoto Protocol expires. Moreover, the Copenhagen Accord is only an offer of co-operation that individual nations can choose to support. A specified goal of maximum 2 degrees increase in global mean temperature was included in the Copenhagen Accord but concrete policy means to attain the goal were missing. Recent analyses indicate that this goal will require that about half of present fossil reserves, especially coal, should remain under ground [Meinshousen et al. 2009 ]. No reference to such a requirement was included in the Copenhagen Accord.

For simplicity, this chapter focuses on $\mathrm{CO}_{2}$ emission from fossil fuels as a dominant contributor to climate change, but $\mathrm{CO}_{2}$ from deforestation as well as emission of methane $\left(\mathrm{CH}_{4}\right)$, laughing gas $\left(\mathrm{N}_{2} \mathrm{O}\right)$ and a number of industrial GHGs should be included in a more comprehensive analysis.

1 nim@byg.dtu.dk 
If the global energy supply system including fuels for the transport sector was completely based on RES a significant part of the problems in relation to climate change could be eliminated. However, even the most optimistic energy experts do not expect this to be the case before the second half of this century, if then. This may well be too late to avoid serious disruptions of the global climate system, likely to be accelerated by exceeding the so-called "tipping points" with positive feed-back effects and irreversible consequences. One example is the release of large quantities of the potent GHG methane $\left(\mathrm{CH}_{4}\right)$ now frozen in tundras in arctic areas. New data refer to an accelerating increase in the $\mathrm{CH}_{4}$ concentration in the atmosphere since 2007 [Dlugokencky and Nisbet 2010].

It should be added that in practice the global potential of RES for energy supply is not unlimited and not without environmental impact. With a growing world population and a growing demand for energy services the practical potential for supply systems based on RES will eventually meet its limits [Trainer 2001]. Furthermore, even if a clean and infinite energy source became available, this might lead to an unrestricted exploitation and pollution of nature with significant losses of natural habitat and biodiversity.

This chapter will address both technological strategies for mitigation of climate change and policy questions such as economic systems, limits to growth, population policies, national and international equity, and alternative employment policies.

The chapter is focusing on developments in affluent countries, such as those in OECD, with the aim of leaving more environmental space for the less developed countries, where growth in material living standard is often a more pressing goal.

\section{Main factors behind climate change}

The main factors behind the present climate change are the growing world population, the material consumption per person and the eco-impact per unit of this consumption. This may be described by the following simple equation:

$$
\mathbf{I}=\mathbf{P} * \mathbf{A} * \mathbf{T},
$$

where I denotes the Impact on the environment, $\mathrm{P}$ is Population, $\mathrm{A}$ is Affluence in the sense of general consumption per person, and $\mathrm{T}$ is a Technological factor representing the ecoimpact per consumption provided [Ehrlich \& Holdren 1971]. These factors are the basis for mitigation of the climate change.

Growth in any one of these three factors will tend to push upwards the total impact, while a decrease will have the opposite effect. In affluent countries solutions are almost as a rule sought in the T-factor, while the two other factors are ignored or even encouraged to grow. A number of theoretical and practical policy concerns for mitigation of global warming are summarized in the following and more details are given in [Daly 2007 and Meyer et al. 2010].

\subsection{Limits to growth and sustainable development:}

Over the last century, development of economics as a discipline has increasingly, with few exceptions, been dominated by a perception of living in an unlimited world with unlimited resources and pollution drains. Resource and pollution problems in one area were supposed to be solved by moving production or people to cleaner and more resource rich parts of the world. The very hint of an overall global limitation as suggested in the report "The Limits to Growth" [Meadows et al. 1972] has generally been met with disbelief and rejection by 
businesses and most economists. However, this rejection was mostly based on false premises as further discussed below.

An early case of concern for sustainable development is published by John Stuart Mill in his chapter "Of the Stationary State" [Mill 1900]. In contrast to most of his contemporary economic colleagues he welcomed and defended the stationary state: "It is scarcely necessary to remark that a stationary condition of capital and population implies no stationary state of human improvement". This line of thought is reflected in to-days controversy between economic schools where ecological economists distinguish between growth and development while the dominating neoclassical school of economics typically uses the two concepts as near synonyms both related to growth in GDP. This is elaborated in more detail in the following.

It has been a barrier for a rational and enlightened discussion that the concepts of growth and sustainable development are used in different and often somewhat conflicting ways. While neoclassical economists typically focus on growth in GDP, modern ecological economics is concerned with physical throughput in economics. In relation to sustainability neoclassical economists require that the utility of future generations is to be non-declining while ecological economists claim that throughput should be sustained. A detailed description of the conflicting use of the concepts is given by Herman Daly in a series of papers [Daly 2007].

Through the 1960s a number of studies revealed the hitherto ignored human and environmental costs of the GDP growth, and in the early 1970s several reports questioned the net blessings of continuing this path [e.g. Schumacher 1973, Goldsmidt et al. 1972]. One of the more extensive studies was initiated by The Club of Rome, resulting in the 1972 report The Limits to Growth (LtG) [Meadows et al. 1972]. The study's results are based on an aggregated computer model, simulating the global development in population, food production, use of non-renewable resources like fossil fuels, industrial output, and in pollution such as the emission of $\mathrm{CO}_{2}$. A key feature of the model is the interactions between these parameters and the delays in the consequences.

The basic conclusion of the LtG report was that continuation of the growth policies in population, industrialization, pollution, food production, and consumption of nonrenewable resources would most likely lead to some kind of collapse during the 21th century, due to resource scarcity, over-pollution, and over-population. Although this catastrophic growth scenario got most attention, alternative scenarios were also presented in the report, including one, which illustrates that it is possible to change course and reach an environmentally sustainable development path, at the same time satisfying all people's physical needs. Finally, the report stressed that due to delays in natural and man-made systems, it is essential for achievement of sustainability that global society acts before the environment undergoes irreversible changes and forces undesired changes upon us.

Many critics of the report focused exclusively on the growth and collapse scenario, and stated in the 1990s that the collapse had failed to materialize. However, this scenario in LtG finds the collapse to occur decades later [Nørgård et al. 2010]. The recent recognition of global warming from increasing $\mathrm{CO}_{2}$ concentration in the atmosphere and an approaching peak in oil supply fits rather well with the growth scenario in LtG. Thus, the real developments in the main parameters in LtG have followed quite closely the main trends in the report's standard scenario, which leads to collapse around 2040 [van Vuuren 2009, Turner 2009]. This underlines the fact that the basic structure and drivers of the global economy have not changed. Not surprisingly, recent environmental reports have presented concepts and warnings similar to those in LtG [Rockström et al. 2009]. Thus, in today's debates on strategies for sustainable development it would be wise to revisit the analysis of the original 1972 version of LtG and its two later revisions [Meadows et al. 1992, Meadows et al. 2004]. 


\subsection{Standard neoclassical economics versus ecological economics:}

Standard neoclassical economics (SNE) is based on an isolated economic system with circular flow of production and consumption. In contrast to this, ecological economics (EE) considers economy as an open subsystem of a finite, non-growing biosphere that is closed with respect to matter but open to a (non-growing) flow of solar energy. A detailed analysis of the differences between the two economic schools has been given by Herman Daly [Daly 2007]. A summary of the main features related to sustainable development follows.

SNE is primarily focused on efficient allocation of resources with minor attention to distribution and typically no attention to scale. EE focuses first on the sustainability of the economic scale and its material through-put. Second priority is given to a just distribution while efficient allocation is positioned lower as a third priority.

SNE is mainly concerned with the variation of a narrowly defined GDP where depletion of natural capital and a number of pollution effects are not included as costs in the accounting. EE points out that growth in GDP may result in uneconomic growth due to depletion of natural capital and pollution effects. The tendency to uneconomic growth is already observed in some OECD countries [Daly 2007].

In recent times a number of studies by economists and other researchers have revealed that in societies where citizens' basic needs are met, further income and consumption seems not to increase people's satisfaction and happiness [Jackson 2009, Jackson 2005, Nørgård 2006]. In other words, in affluent parts of the world, continued growth in GDP is not necessary for a good life. Two Nobel laureates in economics, Joseph Stiglitz and Amartya Sen, stated in their key message in a commission report to the French President Nicolas Sarkozy that "the time is ripe for our measurement system to shift emphasis from measuring economic production to measuring people's well-being" [Stiglitz et al. 2009]. Such a policy shift would be a constructive step in the promotion of sustainable development.

SNE favors global economic integration based on free trade and free capital mobility with reference to the classical argument of "comparative advantage". EE points out that the classical model did not include free capital movement and that internalization of environmental costs tends to be given low priority in a global competition to cut costs and attract capital.

An important sustainability question is related to the concern for intergenerational balance. In standard macroeconomic modeling this is often settled by introducing discount factors for future economic events. However, discount factors of $4 \%$ or higher mean that the welfare of future generations is given low priority. Nevertheless, a number of governments in OECD countries have officially announced discount factors in this range. EE points out that intergenerational balance cannot be satisfied by such a simple technical factor in economic models. The intergenerational distribution problem is a complex one and should take into account that different generations have different goals and priorities. The focus should not be on efficient allocation but on keeping flexible choices and opportunities open for future generations.

The above examples of the differences between SNE and EE should make it clear that the dominating economic school (SNE) is a serious barrier for the promotion of sustainable development. A change in economic policy is required where the principles of ecological economy are given much higher priority. This is not a sufficient condition for sustainable development but a necessary condition. 


\subsection{Population growth:}

Over the last five decades world population has grown from about three to around seven billion. Most of this growth has occurred - and still occurs - in countries with a low $\mathrm{CO}_{2}-$ emission per person. However, in a future where people in these countries are expected to improve their material welfare, the number of people will play a significant role in global environmental problems. According to official UN estimates, world population with no new measures is projected to grow to around 9 billion by 2050 [The Population Council 1998].

In many parts of the Western world population is slowly declining. Government policies in these densely populated, high $\mathrm{CO}_{2}$ emitting, countries often encourage higher birth rates rather than lower, however. Most of the global population growth will, nevertheless, take place in the developing world where current energy consumption per capita is much lower than in industrial countries. In recent decades a number of developing countries, especially in the Asian region, have successfully reduced birth rates to around 2.0 or below [UN Population Div. 2008, Mason 2001]. In general this has been associated with a better material standard of living and better education of the female part of the population.

Fortunately the development of world population is characterized by a large flexibility in options over the long term. Population control is, however, a sensitive issue, and coercive policies often conflict with basic principles of personal freedom. Similarly, birth control may conflict with traditions and religious beliefs. Nevertheless, population policy should be part of any climate change policy

\subsection{Economic and social equity:}

Lack of economic equity nationally and between nations is an important driving force for economic growth. A general argument is that economic growth is needed in order to create more equity, in spite of the fact that in many countries economic growth has actually resulted in less equity.

Economic growth in its present form creates a number of problems for sustainability as described above. At the same time, as expressed by the historian Tony Judt: "It is the growing inequality in and between societies that generates so many social pathologies" [Judt 2010]. Thus, the goal of more equity should be decoupled from the general policy of economic growth and solved by redistribution of wealth and social rights. This will tend to acknowledge and promote economic satiation in affluent societies.

Recognition of a world with limited natural resources will make demands for equal right to the use of these resources more morally and politically legitimate. The complex coupling between inequity, economic growth and sustainability is often overlooked in international negotiations concerning sustainability.

\subsection{Liberalized markets:}

Commercial markets typically have relatively short time horizons e.g. demanding less than five years pay-back time for investments. In contrast to this, desired radical changes of the energy supply systems require planning horizons of 50 years or more. If this is not taken into account, short-sighted investments based on market competition may block necessary long-term solutions. Investments in new coal plants without carbon capture and storage (CCS) and in oil production from tar sand are examples of this.

New systems thinking is needed, in some cases requiring that planning and promotion of investments in vital sectors are transferred from the commercial market to government institutions. This applies in particular to an energy sector which has a goal of sustainable development. 


\subsection{Fear of unemployment:}

One of the main arguments for continued economic growth is based on the experience, that in OECD countries the productivity in the production sector, and to a certain degree also in the service sector, generally increases by about $2 \%$ or more per year. The assumption is that without economic growth this would create more unemployment. This assumption overlooks the flexibility of the employment concept. Rather than considering a lower demand for the workforce due to increased labor productivity as a problem, it should be considered as a blessing due to its associated possibility for an increase in general welfare. A constructive solution to the unemployment problem may be a paid work- sharing program with fewer working hours per week or more vacations.

Other studies focusing on how little labor is needed to provide a decent material standard of living, typically conclude that one or two days of work per week is sufficient (e.g., Gorz 1983). Flexible parameters in this connection are the weekly working hours, the length of vacations, the system of sabbatical leave and the concept of basic income or citizens salary [Meyer et al. 1981].

\section{Energy supply based on renewable energy sources}

In the time perspective of centuries the sustainability criteria require that global energy supply is based on renewable energy sources (RES). However, as mentioned in the Introduction, the transition to an energy supply based on RES cannot wait for centuries due to global climate change from combustion of fossil fuels and to the approaching "peak oil". Thus, if the precautionary principle is taken seriously, this transition should take place before the middle of the present century. This represents an enormous technological challenge requiring new kinds of systems thinking especially in relation to systems based on intermittent RES like solar, wind and waves etc. This section is focused on wind power as one of the significant intermittent global sources for electricity production.

Denmark is used as case study based on its position as a pioneering country in the promotion of modern wind power. One important aspect is the long historical development of the sector in Denmark, which may be traced back to the 1890s [Rasmussen 1987, Grubb and Meyer 1993, Meyer 1995]. This period culminated with the Danish $200 \mathrm{~kW}$ Gedser Mill, in operation from 1959 to 1967 [Rasmussen 1987]. The operation was successful, and the Gedser Mill became the mother of modern Danish wind turbines in the 1970s characterized by three blades on a horizontal axis in an upwind position.

This concept was further developed by a number of small Danish industrial entrepreneurs from the mid-1970s, starting with small turbines (typically rated at about $22 \mathrm{~kW}$ ). While most of these small firms were economically weak a few of them survived and ended up as global leaders of wind turbine production, e.g. the Danish company Vestas. A comparison between wind power penetration in different European countries has shown that the existence of a national wind turbine production is an important factor [Meyer 2007].

The Danish wind power development had early support from acknowledged institutions like the Danish Academy of Technical Sciences (Danish Academy 1975, 1976] and from government programs. This included a test and certification facility. The Danish utilities were generally skeptical about the prospects of Danish wind power but were involved in a few programs in the 1970s.

In the mid-1970s, Danish government commitment to rapid introduction of nuclear power led to significant debate about alternatives. The debate on nuclear energy versus renewable continued for about a decade [Beuse et al. 2000], but was terminated in 1985, when the 
Danish parliament decided that nuclear energy should not be an element of the country's future energy supply. At this time, Danish energy policy was getting ripe for more focus on RES in the electricity system.

\subsection{Danish energy policies and targets}

The Danish strategy for promotion of wind power in the period from the mid seventies to the mid nineties has combined a number of different elements:

- long-term government support for research, development and demonstration;

- national tests and certification of wind turbines;

- $\quad$ government sponsored wind energy resource surveys (wind atlases);

- $\quad$ subsidies, feed-in tariffs and regulations;

- local ownership of wind turbines and careful selection of sites.

These elements will be discussed in more detail in the following.

The shift in the focus of Danish energy policy after 1985 was confirmed by new official energy plans in 1990 [Danish Ministry of Energy 1990] and 1996 [Danish Ministry of Environment and Energy 1996]. Now, the overall goal of Danish energy policy was to create a sustainable energy system and reduce GHG emission. Policy strongly promoted the development of RES and the expansion of electricity generation based on renewable energy sources. The specific target for RES in these plans was 12-14 \% of primary energy by 2005 and $35 \%$ coverage by 2030 .

Wind power was given an important role in these plans with targets for installed capacity of around $1500 \mathrm{MW}$ in 2005 and $5500 \mathrm{MW}$ in 2030, covering $10 \%$ and up to $50 \%$ of Danish electricity consumption, respectively. The 2030 target includes $4000 \mathrm{MW}$ of offshore wind capacity.

In practice, the 2005 target was exceeded by a factor of two by 2003, with installed wind power capacity of around $3000 \mathrm{MW}$. This corresponds to nearly $19 \%$ of Danish electricity consumption. Since then, the growth of installed wind capacity has stagnated due to a change in energy policy. The mechanisms behind this development of growth and subsequent stagnation are analyzed in more detail in the following.

\subsection{Research, development and resource assessment}

A marked feature of Danish wind power development is its "safe" technical path, with a gradual increase in turbine size based on improvements of the same basic design, starting with typical rated powers of about $20 \mathrm{~kW}$ in the mid-1970s and leading to MW capacities today. Establishing market credibility was integral to this approach. A machine-testing program was established at Risø National Laboratories in 1978. About a year later, a formal certification procedure was added. This program has been essential in preventing substandard technologies from being marketed both at home and abroad, presenting a marked contrast with California in the early 1980s, where early expansion born of generous financial incentives foundered on the poor reliability of the machines installed [van Est 1999].

A further component to Denmark's supportive developmental context was the publication in 1981 of a wind atlas for Denmark, based on the pioneering work of E. L. Petersen and co-workers at Risø National Laboratories [Petersen et al. 1981]. Computational procedures described in the atlas made it possible to estimate the wind distribution over heterogeneous terrain and to map the wind energy resource with higher accuracy than from general meteorological data. This enabled an extensive national assessment study on sites for wind turbines to be conducted from 1981 to 1986 by Danish authorities [Danish Energy Authority 1986]. 
In 1982 a government committee was established for promoting energy systems based on RES, including wind, solar and biomass. In the late 1980s, the committee promoted new programs of offshore wind farms in order to overcome the foreseen obstacles for land-based turbines (see below).The total funding for RES from the committee during its nine years of operation amounted to about 30 million $€$.

\subsection{Economic support schemes}

From 1979, private citizens who installed certified wind turbines were reimbursed $30 \%$ of the turbine's purchase price by the Danish government. As wind power economic improved during the 1980s, the investment subsidy was gradually reduced to $10 \%$. In 1989, it was finally eliminated after a total investment subsidy of about 280 million DKK (37 million $€$ ) contributing to the installation of about $300 \mathrm{MW}$ rated wind power.

After a number of disagreements between utilities and wind power producers over conditions for grid connection and tariffs, regulations were introduced by the Danish government in 1992. This included a feed-in tariff which was fixed at $85 \%$ of the utility production and distribution costs. On top of the feed-in tariff from the utilities, the private wind power producers would receive a tax refund ("environmental premium") of 0.27 DKK per $\mathrm{kWh}$ (3.6 eurocents per $\mathrm{kWh}$ ). After a drop in the yearly growth of wind capacity in the early 1990s, this initiated a strong growth in land-based wind capacity in the last part of the 1990s (Figure 1).

\section{Yearly growth in number of turbines and capacity in Denmark}

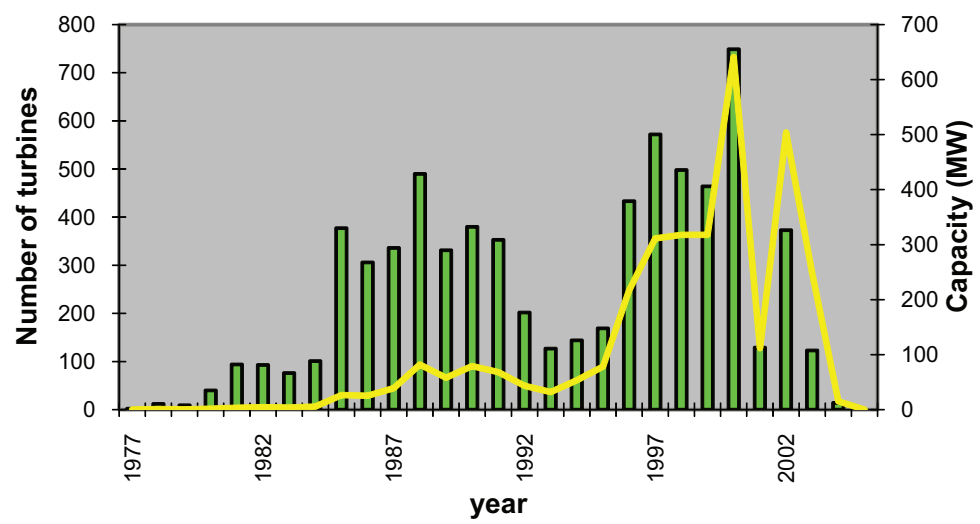

Fig. 1. Yearly growth in number of turbines in Denmark (bars) and annual installed capacity (line) from 1977 to 2005 (Danish Energy Authority). From 2005 to 2010 the net annual increase in capacity has been close to zero due to a change in government policy.

The success of wind power in Denmark and other European countries like Germany and Spain is mainly due to the so-called Feed-In Tariffs (FITs) where owners of wind turbines are guaranteed a favorable tariff on a long term basis, often combined with priority access to the grid. The same type of scheme may be used for other intermittent RES like PV and wave power. Flexibility may be introduced by yearly reductions in the tariffs for new plants as the technology matures [Bechberger \&Reiche 2007]. 
A competing scheme in Europe is called Trading of Green Certificates (TGC) with certificates issued to individual wind power producers in accordance with a specified government target for the total national wind power production and with sanctions to utilities if the target is not fulfilled. In the US this scheme is called Renewables Portofolio Standard (RPS). A comparison of the European and the US experiences may be found in [Rickerson \& Grace 2007].

Neither the FIT nor the TGC operates in accordance with traditional market principles. In the case of FIT the price of the wind electricity is fixed while the volume is decided by the market; the opposite applies to TGC. A number of variations of these two schemes may be found in different countries e.g. in the US [Schreurs 2007]. The advantages and problems of the FIT and TGC schemes have been discussed by Hvelplund and Meyer [Hvelplund 2001a, 2001b, 2005, Meyer 2003]. It is concluded that the FIT so far has been most efficient for promotion of wind power as illustrated by the wind power development in Denmark, Germany and Spain [Meyer 2003].

It is not relevant to force intermittent RES like wind power into the traditional market system, when the main goal is to accelerate its penetration into the electricity supply system. After the investment has been made in a wind turbine, there is no way that the investor can compete more efficiently by cutting running costs or improving the production efficiency. It all depends on the wind. This also supports the priority for the FIT scheme and its general application in a system with priority for establishing a sustainable energy supply.

The political opposition to the FIT has mainly been based on economic complaints that the favorable tariff combined with priority for wind results in higher electricity prices for the consumers compared to electricity from e.g. coal plants. However, it should not be overlooked, that wind power in many cases provides lower consumer prices on the electricity market by outcompeting power sources with high marginal prices. The least cost-effective power plants close down when the wind blows. An analysis of the Danish power market from 2005 to 2008 has shown that the cost of power to the consumer (excluding taxes and transmission and distribution tariffs) would have been 5 to $10 \%$ higher if wind had not been contributing to power production [Munksgaard \& Morthorst 2008, Wind Directions 2010].

\subsection{Local ownership of wind turbines and careful planning of sites}

Social acceptability is widely recognized as an important factor influencing wind energy deployment. Public attitude surveys of wind power in the 1990s generally showed that around $80 \%$ of the Danish population supported wind power [Danish Wind Industry Association 1993, Damborg 1999]. However, that this general support translated into local acceptance of specific projects can be attributed largely to the fact that most Danish turbines were owned by private households based on neighbouring cooperatives. About 150,000 Danish households were registered as owners of shares in wind in 2001. It is easier to accept some extra noise and the view of a turbine if it reminds you of the fact that the turbine gives you money when the wind blows. Such externalities have, in any case, been reduced by more modern turbines, minimum separation distances from dwellings, and careful attention to turbine siting and design.

Strict rules for investors were another factor promoting local accept of wind turbines. Thus, owners of wind turbines in a community had to live in this community or in a neighboring community. When this restriction was cancelled in 2000 local opposition to wind turbines were growing in Denmark. 


\subsection{Offshore wind farms in Danish waters}

Offshore wind farms were proposed as a promising solution in relation to onshore site constraints by the Danish governmental RES committee in the late 1980s. Subsequently, the first offshore wind farm in the world became operational in September 1991 at Vindeby - a site northwest of the Danish island Lolland in the Baltic Sea. A second offshore wind park became operational in October 1995 at Tunø Knob between Jutland and the island of Samsø. A special investigation concerning the impact on bird habitats has been carried out in connection with this project. This problem has turned out to be negligible. Since then, a number of Danish offshore wind farms have been installed (see Table 1).

\begin{tabular}{|c|c|c|c|}
\hline Year & Place & $\begin{array}{c}\text { Number of } \\
\text { turbines }\end{array}$ & $\begin{array}{c}\text { Total capacity } \\
\text { (MW) }\end{array}$ \\
\hline 1991 & Vindeby & 11 & 5 \\
\hline 1995 & Tunø Knob & 10 & 5 \\
\hline 2001 & Middelgrunden & 20 & 40 \\
\hline 2002 & Horns Reef 1 & 80 & 160 \\
\hline 2003 & Nysted & 72 & 166 \\
\hline 2003 & Rønland & 8 & 17 \\
\hline 2003 & Samsø & 10 & 23 \\
\hline 2009 & Sprogø & 7 & 21 \\
\hline 2009 & Horns Reef 2 & 91 & 209 \\
\hline 2010 & Avedøre Holme & 3 & 11 \\
\hline 2010 & Rødsand & 90 & 207 \\
\hline 2012 (planned) & Anholt & To be decided & 400 \\
\hline
\end{tabular}

Table 1. Offshore Danish wind farms.

Some of the Danish offshore wind farms have been installed based on a tender procedure including conditions in relation to grid connections and tariffs. The first tender for a second $200 \mathrm{MW}$ wind farm at Horns Reef in the North Sea in 2006 resulted in a tariff of 0.53 $\mathrm{DKK} / \mathrm{kWh}$ (7.1 eurocents/kWh). The latest tender (2010) for a $400 \mathrm{MW}$ wind farm at the island of Anholt resulted in a tariff of 1.06 DKK (14 eurocents/kWh). There was only one bidder and the high tariff is partly due to stringent conditions and partly influenced by high international offshore tariffs, e.g. favorable government conditions for offshore farms in the UK.

\subsection{Impact of government policy}

A striking illustration of the influence of national energy policy is given in Fig. 1, most dramatically by the stagnation of the wind power development after a change of government in November 2001. The new conservative-liberal government cancelled most of the previous support for RES and replaced it by a reliance on commercial market forces. Danish wind producers have received the lowest unit price among the old 15 member states of EU under the new government that is still in power in 2010.

As a consequence the net increase in installed wind power in Denmark has been close to zero since 2003. The major contribution to increased capacity on land has been re-powering of existing wind turbines with higher capacity turbines, rather than opening up of new sites. At the same time there has been a growing local opposition to new wind turbines as the government has cancelled geographical restrictions on investors resulting in reduced economic advantages to the local community. 


\subsection{Grid system balance}

Coverage by intermittent wind power of more than $20 \%$ of the total electricity consumption gives rise to new regulation problems, especially in combination with a high percentage of heat-bound co-generation like in Denmark. One solution is to expand the transmission capacity to neighboring countries but this may not be the optimal solution as discussed in the Danish CEESA project [CEESA 2010]. An alternative solution may be based on coordinated production between wind turbines and distributed and flexible Combined Heat and Power (CHP) plants. A project along these lines is taking place in Western Denmark involving the development of a "Cell Architecture" for decentralized grid management of semi-autonomous cells with well-defined local functions and system-wide coordination capabilities [Lund et al. 2006].

In a longer time perspective, the transport sector should be included in a comprehensive energy system, where electric cars can play a significant role as storage element in the electric supply system [Lund 2010, CEESA 2010].

\section{Conclusions}

The process of international climate negotiations from Bali to COP15 in Copenhagen has illustrated the need for new and supplementary schemes for mitigation of climate change. This chapter presents proposals for new strategic thinking to overcome present barriers and promote efficient schemes for sustainable energy development. The chapter's main conclusions are summarized as follows:

- A new economic paradigm is needed with less attention to GDP and more attention to sustainability and welfare. This involves, among other things, a shift in the present balance between societal planning and commercial market principles to the advantage of long range societal planning. Economic science should give high priority to the development of market constructs that leads to sustainable development.

- The level of the global population is an important factor in relation to global warming and demand for energy. Thus, regulation of birth rates should not be a taboo subject.

- Lack of economic and social equity is a serious barrier for sustainable development. More equity globally and within nations is needed.

- Limits to growth on a finite planet should be recognized. It is necessary to change the institutional market conditions in which households are embedded.

- Present employment policies promote material growth. The alternative is sharing of paid work and more free time. Introduction of a general citizens salary (basic income) may be worth pursuing.

- Stronger promotion of renewable energy and energy conservation is needed.

- Important factors for the penetration of wind power in a country (besides the wind potential) are the existence of a national turbine production, official government targets, favorable feed-in tariffs and favorable conditions for grid connections.

- In order to avoid local opposition to land-based turbines, the rules should secure economic advantages to local communities in connection with new wind parks.

- Wind power should not be included in traditional commercial market systems. The penetration of wind power can be promoted by flexible feed-in systems.

- New distributed and flexible systems in combination with storage in electric cars can allow high coverage of wind power in the supply system. 


\section{Acknowledgements}

Thanks are due to my colleagues, professors Jørgen S. Nørgård and Frede Hvelplund for valuable discussions, especially on the subjects of limits to growth and neoclassical economics. Parts of the work behind this chapter have been supported economically by the research project Coherent Energy and Environmental System Analysis (CEESA), partly financed by The Danish Council for Strategic Research

\section{References}

Bechberger M and Reiche D (2007) "Diffusion of Renewable Feed-in Tariffs in the EU-28", chapter in "Green Power Markets", edited by Lutz Mez, pp. 31-50, Multiscience Publishing, UK.

Beuse E, Boldt J, Maegaard P, Meyer NI, Windeleff J and Østergaard I (2000) "Renewable Energy in Denmark - History of 25 Years of Growth 1975 to 2000" (in Danish), OVE Publishers. Aarhus, Denmark.

CEESA (2010), www.ceesa.dk

Copenhagen Accord (2009), www.un.org/climatechange.

Daly HE (2007) "Ecological Economics and Sustainable Development", in Advances in Ecological Economics, Edward Elgar Publishers, Northhampton, MA, USA.

Damborg S (1999) "Public Attitudes Towards Wind Power" (in Danish), Danish Wind Industry Association. www.windpower.dk

Danish Academy of Technical Sciences (1975) “Wind Power" (in Danish), Copenhagen, Denmark.

Danish Academy of Technical Sciences (1976) "Wind Power 2 - Proposal for an Action Programme" (in Danish), Copenhagen, Denmark.

Danish Energy Authority (1986) "Large Windmills in Denmark", Copenhagen, Denmark.

Danish Ministry of Energy (1990) "Energy 2000 - A plan of Action for Sustainable Development", Copenhagen, Denmark.

Danish Ministry of Environment and Energy (1996) “Energy 21 - The Danish Government's Action Plan for Energy". Copenhagen. Denmark.

Danish Wind Industry Association (1993) "Attitudes on Wind Power" (in Danish), Ringkøbing, Denmark.

Dlugokencky E and Nisbet E (2010) “Global Atmospheric Methane in 2010: Budget, Changes and Dangers", presented at the Royal Society, London, UK, February 2010.

Erlich P and Holdren JP (1971) "Impact of Population Growth". Science, New Series, Vol. 171, No. 3977, pp 1212-1217.

Goldsmith E, Allen R, Allaby M, Davoll J and Lawrence S (1972) “A Blueprint for Survival”, The Ecologist, 2, no 1 (1972).

Gorz A (1983) "Les chemins du Paradis, L'agonie du Capital”, Edition Galilée, Paris, France.

Grubb MJ and Meyer NI (1993) "Wind Energy: Resources, Systems, and Regional Strategies", in Renewable Energy: Sources for Fuels and Electricity, edited by T.B. Johansson, H. Kelly, A.K.N Reddy and R.H. Williams. Washington D.C. Island Press: pp. 157-212.

Hansen J, Sato M, Karecha P, Beerling D, Berner R, Masson-Delmotte V, Pagani M, Raymo M, Royer DL and JC Zachos (2008): Target Atmospheric CO2: Where Should Humanity Aim? Open Atmospheric Science Journal. arXiv:0804.1126v2 [physics.ao-ph]. 
Hvelplund F (2001a) "Renewable Energy Governance Systems", Department of Development and Planning, Aalborg University, Denmark. http://www.windorks.org/FeedLaws/ARTsGovernance.html

Hvelplund F (2001b) "Political prices or political quantities?: A comparison of renewable energy support systems", New Energy, No. 5.

Hvelplund F (2005) “Renewable energy: Political prices or political quantities" in: Switching to renewable power: a framework for the $21^{\text {st }}$ century/red Volkmar Lauber. London: Earthscan, pp. 228-245.

IPCC (2007) "Climate change 2007: The physical science basis. Contribution of Working Group I to the fourth assessment report of the Intergovernmental Panel on Climate Change". [Solomon, S., D. Qin, M. Manning, Z. Chen, M. Marquis, K.B. Averyt, M. Tignor and H.L. Miller (Eds)]. Cambridge, UK and New York, USA, Cambridge University Press.

Jackson $\mathrm{T}$ (2006) "Live better by consuming less? Is there a 'double dividend' in sustainable consumption?", Journal of Industrial Ecology, 9 (1-2), pp. 19-36.

Jackson T (2009) "Prosperity without Growth - Economics for a Finite Planet". Earth Scan, London, UK.

Judt T (2010) "Ill fares the land", Penguin Books, UK.

Kopp RE., Simons FJ, Mitrovica KX, Maloof AC and Oppenheimer M (2009) "Probabilistic assessment of sea level during the last interglacial state", Nature 462, pp. 86-867.

Lund H (2010) "Renewable Energy Systems", Elsevier, Amsterdam, the Netherlands.Layard, R (2006). "Happiness - Lessons from a New Science", Penguin, London, UK.

Lund P, Cherian S and Ackermann T (2006) "A Cell Controller for Autonomous Operation of a $60 \mathrm{kV}$ Distribution Area, International Journal of Distributed Energy Resources 2, pp. 83-100.

Mason A ed. (2001) "Population Policies and Programs in East Asia", East West Center, Occasional Papers. Population and Health Series, No. 123.

http:// www.eastwestcenter.org/fileadmin/stored/pdfs/POPop123.pdf

Meadows DH, Meadows DL, Randers J and Behrens III WW (1972) “The Limits to Growth", Universe Books, New York, USA.

Meadows DH, Meadows DL and Randers J (1992) "Beyond the Limits", (Earthscan Publications Limited, London, UK).

Meadows DH, Randers J \& Meadows DL (2004) "Limits to Growth. The 30 Years Update", Chelsea Green, White River Junction, Vermont, USA.

Meinshausen M, Meinshausen N, Hare W, Raper SCB, Frieler K, Knitti R, Frame DJ and Allen MR (2009) "Greenhouse-gas emission targets for limiting global warming to $2^{\circ} \mathrm{C}^{\prime \prime}$, Nature, 458 (7242), pp. 1158-1162.

Meyer NI (1995) “ Danish Wind Power Development”, Energy for Sustainable Development 2: pp.18-25.

Meyer NI (2003) "European Schemes for Promoting Renewables in Liberalised Markets", Energy Policy, 31, pp. 665-676.

Meyer NI (2007) "Learning from Wind Energy Policy in the EU: Lessons from Denmark, Sweden and Spain", European Environment 17, pp. 347-362.

Meyer NI., Petersen KH and Sørensen V (1981): "Revolt from the Center", Marion Boyars Publishing, London, UK.

Meyer NI, Hvelplund F and Nørgård JS (2010) "Equity, Economic Growth and Lifestyle", chapter in Energy Sustainability and the Environment: Technology, incentives, behavior, F. Sioshnsi Ed., Elsevier, the Netherlands, forthcoming. 
Mill JS (1900) "Principles of Political Economy" (original version published in 1848). Revised edition, Vol. II, Colonial Press, New York, USA.

Munksgaard J and Morthorst PE (2008) "Wind power in the Danish liberalised power market - Policy measures, price impact and investor incentives", Energy Policy 36, pp.3940-3947.

National Research Council (2010) "Climate Stabilization Targets: Emissions, Concentrations, and Impacts over Decades to Millenia", The National Academic Press, Washington D.C:, USA.

Nørgård JS. (2006) “Consumer efficiency in conflict with GDP growth”, Ecological Economics, 57, pp. 15-29.

Nørgård JS, Peet J and Ragnarsdóttir KV (2010). "The history of The Limits to Growth", Solutions, vol 1, No 2, March-April, pp. 59-63. http://www.thesolutionsjournal.com/node/569.

Petersen EL, Troen I, Frandsen S and Hedegaard K (1981) "Wind Atlas for Denmark", Risø National Laboratory. Roskilde, Denmark.

Rasmussen B (1987) " Power Production from the Wind", in "Wind Energy in Denmark", report from the Danish Ministry of Energy, Copenhagen, Denmark.

Rickerson W and Grace RC (2007) "The Debate over Fixed Price Incentives for Renewable Electricity in Europe and the United States: Fallout and Future Directions", A White Paper prepared for the Heinrich Böll Foundation, Berlin, Germany.

Rockström J et al.(2009) "A safe operating space for humanity". Nature, 461, 472, 24. Sept.

Schreurs MA (2007) "Renewable Energy Politics in the United States", in Green Power Markets: Support Schemes, Case Studies and Perspectives", edited by Lutz Mez, Multiscience Publishing, UK, pp. 227-250.

Schumacher EF (1973) "Small is Beautiful - a study of economics as if people mattered", Blond \& Briggs, London, UK.

Stiglitz JE, Sen A and Fitoussi J-P (2009) "Report by the Commission on the Measurement of Economic Performance and Social Progress", Paris, France, www.stiglitz-senfitoussi.fk

The Population Council (1998) "UN World Population Projections to 2150". The Population Division of the United Nations Population Secretariat. Population and Development Review,24, No 1 (March, 1998), pp. 183 - 189. http:/ / www.jstor.org/stable/2808146.

Trainer FE (2001) "Natural Capitalism Cannot Overcome Resource Limits", http://www.mnforsustain.org/trainer_fe_simon_lovins_critique.htm.

Turner GM (2009) "A Comparison of the 'Limits to Growth' with 30 Years of Reality", Global Environmental Change, http://www.csiro.au/files/files/plje.pdf.

UN Population Division (2008) "World Population Policies 2007", Department of Economic and Social Affairs. United Nations, New York, USA. http://www.un.org/esa/ population/publications/wpp2007/Publication_index.htm

van Est R (1999) "Wind of Change - A Comparative Study of the Politics of Wind Energy Innovation in California and Denmark", Dr. Thesis, University of Amsterdam, the Netherlands.

van Vuuren DP and Faber A (2009) "Growing within Limits - A Report to the Global Assembly 2009 of the Club of Rome", The Netherlands Environmental Assessment Agency. Bilthoven, The Netherlands.

http:/ / www.rivm.nl/bibliotheek/rapporten/500201001.pdf.

Wind Directions (2010) "Wind: lowering electricity prices", European Wind Industry Magazine, 29, no.2, pp. 18-19. 


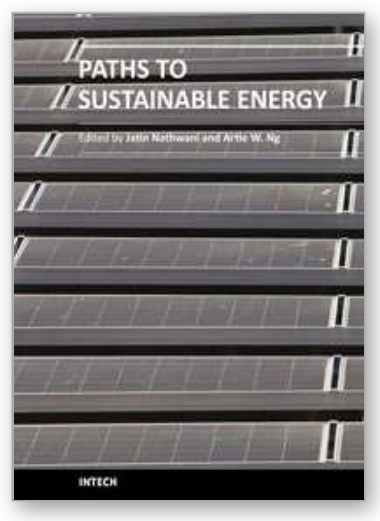

\author{
Paths to Sustainable Energy \\ Edited by Dr Artie $\mathrm{Ng}$
}

ISBN 978-953-307-401-6

Hard cover, 664 pages

Publisher InTech

Published online 30, November, 2010

Published in print edition November, 2010

The world's reliance on existing sources of energy and their associated detrimental impacts on the environment- whether related to poor air or water quality or scarcity, impacts on sensitive ecosystems and forests and land use - have been well documented and articulated over the last three decades. What is needed by the world is a set of credible energy solutions that would lead us to a balance between economic growth and a sustainable environment. This book provides an open platform to establish and share knowledge developed by scholars, scientists and engineers from all over the world about various viable paths to a future of sustainable energy. It has collected a number of intellectually stimulating articles that address issues ranging from public policy formulation to technological innovations for enhancing the development of sustainable energy systems. It will appeal to stakeholders seeking guidance to pursue the paths to sustainable energy.

\title{
How to reference
}

In order to correctly reference this scholarly work, feel free to copy and paste the following:

Niels I. Meyer (2010). New Systems Thinking and Policy Means for Sustainable Energy Development, Paths to Sustainable Energy, Dr Artie Ng (Ed.), ISBN: 978-953-307-401-6, InTech, Available from: http://www.intechopen.com/books/paths-to-sustainable-energy/new-systems-thinking-and-policy-means-forsustainable-energy-development

\section{INTECH}

open science | open minds

\author{
InTech Europe \\ University Campus STeP Ri \\ Slavka Krautzeka 83/A \\ 51000 Rijeka, Croatia \\ Phone: +385 (51) 770447 \\ Fax: +385 (51) 686166 \\ www.intechopen.com
}

\author{
InTech China \\ Unit 405, Office Block, Hotel Equatorial Shanghai \\ No.65, Yan An Road (West), Shanghai, 200040, China \\ 中国上海市延安西路65号上海国际贵都大饭店办公楼405单元 \\ Phone: +86-21-62489820 \\ Fax: +86-21-62489821
}


(C) 2010 The Author(s). Licensee IntechOpen. This chapter is distributed under the terms of the Creative Commons Attribution-NonCommercialShareAlike-3.0 License, which permits use, distribution and reproduction for non-commercial purposes, provided the original is properly cited and derivative works building on this content are distributed under the same license. 